\title{
A FORMAÇÃO DA NAÇÃO E O VAZIO NA NARRATIVA ARGENTINA: FICÇÃO E CIVILIZAÇÃO NO SÉCULO XIX
}

\author{
José Alves de Freitas Neto* \\ UNICAMP
}

\begin{abstract}
Resumo:O conto El Matadero de Esteban Echeverría (1805-1851) é um relato fundador que explicita as tensões vividas no território argentino no período do governo do caudilho Juan Manuel de Rosas. Ultrapassando as dicotomias entre federalistas e unitaristas, El Matadero é uma crítica à população de Buenos Aires que apoiava o governo do caudilho. Echeverría construiu uma metáfora do processo político daquele país e nos permite a leitura de um vazio civilizacional em sua descrição sobre os habitantes da cidade e, ao mesmo tempo, os paradoxos para que se pudesse atingir o projeto do grupo de liberais ilustrados portenhos.
\end{abstract}

Palavras-chave: Echeverría; El Matadero; nação; Argentina.

\section{The nation formation and the blank in the argentine narrative: fiction and civilization in $19^{\text {th }}$ century}

\begin{abstract}
The tale El Matadero by Esteban Echeverría (1805-1851) is like a establisher report that make explicit the tensions deeply experienced at Argentina on the years of Juan Manuel de Rosas government. Exceeding the dichotomous limits between federalists and unitarists, El Matadero is a criticism on to Buenos Aires people who supported the caudillo Rosas and his authority. Actually, Echeverría frames a metaphor about the Argentinean political process in which we can see empty spaces in its "civilization" (it is like a civilizational vacuum) when he describes the townsmen and, at the same time, he shows us the paradoxes within for the reaching the project from liberals and illustrated porteños.
\end{abstract}

Keywords: Echeverría; El Matadero; nation; Argentina

\footnotetext{
* Agradeço aos pesquisadores e amigos: Priscila Pereira, Juliana Lopes, Janice Theodoro, Leandro Karnal e Anderson Roberti dos Reis pela leitura e sugestões apresentadas; a Jean Claude Laborie pela proposição do desafio de pensar a temática do excesso/vazio na América. Este texto foi apresentado, de forma sucinta, durante o VII Encontro Internacional da ANPHLAC (Associação Nacional de Pesquisadores de História Latino-americana e Caribenha), realizado na PUC-Campinas, em outubro de 2006.

Dedico este texto à memória do Professor Héctor Hernán Bruit, professor livre-docente da Unicamp, que tanto contribuiu para o crescimento da área de História da América no Brasil. Sua ausência deixa um imenso vazio entre os que o admiravam.
} 
$\mathrm{Na}$ origem dos atuais estados políticos que compõem a América Latina, a literatura teve uma função pedagógica extremamente relevante por estabelecer estereótipos, narrar contradições e sinalizar os espaços de cada grupo étnico, social e político dentro das disputas internas dos países que se originaram do antigo Império Espanhol.

Este aspecto de uma literatura de fundação, que persiste ainda hoje como cânones desses Estados, relaciona-se historicamente com uma determinada projeção realizada pelos literatos do século XIX. Seus valores políticos, morais e estéticos saltam das páginas e povoam certo imaginário sobre as origens destas unidades políticas independentes da América hispânica. Os literatos que registraram episódios recriando tipologias sobre os habitantes das antigas colônias espanholas legaram às gerações posteriores a oportunidade de rastrear, por meio do discurso ficcional, os embates vividos nas primeiras décadas do século XIX. Quase duzentos anos depois, os escritos desses homens de letras continuam instigando a reflexão de historiadores e estudiosos ao revelar as tensões e os projetos de nações que surgiam. Na América hispânica da atualidade ainda ecoam questões sobre as identidades, o futuro e as contínuas avaliações sobre o passado.

Estas perguntas recorrentes se explicam também pela necessidade de particularizar o que cada país procurou realizar durante a sua formação. O antigo território colonial ibérico fragmentou-se e cada uma das novas regiões autônomas empreendeu esforços para se individualizar em relação às áreas vizinhas. O passado colonial, cujos traços do domínio espanhol conferiam certa uniformidade aos vicereinos e capitanias, foi rediscutido por intelectuais e literatos na formação dos novos países.

$\mathrm{Na}$ Argentina, por exemplo, foram freqüentes os debates sobre sua nova condição política. As divisões internas diante do espólio colonial espanhol dividiram politicamente o que seria o futuro território do país austral. A crença em um futuro modernizador levou os políticos liberais a questionar as práticas consolidadas e, ao mesmo tempo, a sinalizar outros processos históricos que tinham um perfil hierarquizador. Um setor defendia uma ordem "moderna" e o outro representava uma tradição "arcaica". Estes dualismos favoreceram as explicações esquemáticas, mas na prática, as divergências eram mais complexas. $\mathrm{O}$ tema principal da Argentina do século XIX foi apresentado por Domingo Faustino Sarmiento ao escrever o clássico "Facundo: civilização e barbárie" (1845).

O dilema do tema civilização e barbárie é a ambigüidade que cada uma destas palavras carrega. $\mathrm{O}$ discurso tem origens que se vinculam a um grupo específico de ilustrados e liberais que excluem parte dos habitantes daquele território do debate. A população é o alvo das reflexões, mas não é o interlocutor da discussão ${ }^{1}$. Mas antes deste discurso assumir a forma elaborada por Sarmiento, outros escritores já abordavam o projeto de nação a ser buscado pela Argentina e qual o papel de sua 
população. Dentre estes está o breve conto de Esteban Echeverría (1805-1851), El Matadero, escrito em 1838 e publicado em 1871. O conto nos remete a um processo de disputas políticas e culturais ocorridas em Buenos Aires durante o governo do caudilho Juan Manuel de Rosas. Ao lançar o olhar sobre a população portenha podemos identificar uma narrativa que expõe a fragilidade do processo modernizador dos liberais argentinos. Além da evidente denúncia da presença de forças e violências excessivas da história argentina representadas no conto de Echeverría, o aspecto mais importante do texto a ser apreendido, é a noção de 'vazio' que ele expressa ao descrever a multidão, que tem a responsabilidade de legitimar sua participação na construção do Estado.

\section{As divisões políticas e o 'vazio' no projeto de nação liberal argentino}

As divisões políticas ocorridas na futura Argentina expressavam as angústias frente às mudanças após o processo de emancipação política iniciado em 1810. A tensão entre o progresso, que representaria o ato de civilizar-se, e a adoção de um procedimento político em torno de figuras carismáticas e poderosas, o caudilhismo ${ }^{2}$, era cada vez mais evidente. Durante os governos de Juan Manuel de Rosas (182932; 1835-1852), a oposição ilustrada e liberal, utilizava-se da representação literária para denunciar as práticas de Rosas e, no caso de Echeverría, o forte apoio popular que o líder político obtinha.

A produção escrita dos liberais tinha um papel pedagógico e político em definir como meta a civilização ${ }^{3}$. Os políticos liberais argentinos, por meio desta temática civilizacional, estabeleciam uma filiação à história universal capitaneada pelas discussões européias que relacionavam civilização e progresso. Partindo de uma premissa teleológica de que haveria uma vitória do campo "civilizador", estes políticos e intelectuais construíram um projeto de conquista de poder, na qual a queda de Rosas seria difícil, mas inevitável. Porém, o maior obstáculo à execução deste projeto não seria a remoção do caudilho, mas a persistência do "barbarismo" entre a população. ${ }^{4}$

A oposição entre civilização e barbárie discutida internamente também se relacionava com os modelos externos. Para muitos a civilização era a Europa, e o melhor exemplo a ser seguido, a França. Em oposição, o legado espanhol deveria ser esquecido. Entre o Velho Mundo civilizado e a América bárbara, a cidade de Buenos Aires era vista como um posto avançado da civilização e isolada num continente "vazio" e selvagem. O isolamento portenho era evidente na divisão do país entre federalistas, que defendiam maior poder às províncias e maior liberdade para os caudilhos interioranos, e unitários, que se opunham a este projeto e defendiam a centralização do poder a partir de Buenos Aires. Esta oposição marcou o país durante o século XIX, incluindo muitos conflitos entre os "argentinos". 
O olhar dos "civilizados" em relação ao interior, visto como um extenso território, gerava a idéia de um mundo inacabado, no qual a solidão e a presença de grandes áreas desocupadas eram aspectos indissociáveis. Este discurso produzido à época ignorava que existiam sociedades anteriores, ou melhor, as antigas formas de sociabilidades deveriam ser esquecidas, o que significava alijar os camponeses (representado pela figura do gaucho) e os indígenas do processo de formação da nação.

Sem a presença de grande parte da população construiu-se um dos grandes paradoxos das nações hispano-americanas. Ao mesmo tempo em que determinados setores defendem idéias liberais, que incluem a vontade dos habitantes para que haja legitimidade no exercício do poder capaz de se contrapor à ordem colonial espanhola, esse mesmo povo, alçado à condição de legitimador das decisões políticas, é retratado como "inculto", analfabeto, cheio de "superstições". Por esta visão, graças à preservação de determinados costumes e práticas culturais dos grupos populares, eles seriam incapazes de conduzir sua própria história.

A radicalidade deste discurso na Argentina, como podemos observar em El Matadero, está relacionada à suposta clareza política das lideranças sobre os projetos por elas empreendidos. A "vontade geral" da população deveria ser decifrada e levada a termo por esses homens letrados que seriam capazes de realizar a construção da República na região. A ficção argentina, portanto, é instauradora de uma significação política que apresenta um continente "vazio". O vazio deve ser compreendido não como a ausência, mas como espaço do que é faltante. Echeverría, nosso principal objeto de análise, não ignorava a presença da população, mas registrava o tipo de comportamento que ela expressava e a distância entre o que se praticava e o que se almejava para uma nação civilizada. Para o literato e político havia um percurso a ser seguido e, portanto, o vazio precisava ser descrito e preenchido. É o oposto das temáticas convencionais do excesso - o olhar deste escritor argentino estava na demanda que seria produzida sobre o país, levando-o a se civilizar 5 .

\section{Echeverría e a Geração de 37}

Segundo Alberto Palcos, em seu livro, Echeverría y la democracia argentina $^{6}$, os dados biográficos do autor de El Matadero expressam uma dor que se confunde com a sua literatura e com os posicionamentos políticos adotados. Esteban Echeverría nasceu em Buenos Aires em 1805, perdeu seu pai na infância e teve uma juventude rebelde, que expressava seu desejo de maior liberdade pessoal. Ainda jovem perdeu a sua mãe. Após um envolvimento amoroso tumultuado, teve que sair de Buenos Aires, no final de 1825, e foi para a Europa. No período em 
que viveu em Paris (1826-1830) conheceu o movimento romântico europeu que o influenciou em sua produção.

No regresso a Buenos Aires iniciou sua produção literária e integrou as reuniões políticas e literárias promovidas pelo livreiro Marcos Sastre. Nestes encontros, ocorridos em 1837, discutiam-se, dentre outros, Victor Hugo, Cousin e Byron. Outros integrantes de destaque do Salão Literário eram Juan Bautista Alberdi e Juan Maria Gutiérrez. Este grupo ficou conhecido como a Geração de 37, que marcou a história do pensamento argentino por lançar dois desafios complementares: identificar os problemas que o país enfrentava e o estabelecimento de uma nação moderna. ${ }^{7}$

A vida do Salão Literário foi curta, graças à perseguição rosista. Em 1838, buscando preservar os ideais do grupo, os jovens escritores, sob a liderança de Echeverría, criaram a Asociación de la Joven Generación Argentina, também chamada de Joven Argentina que foi rebatizada mais tarde como Asociacón de Mayo. A troca do nome, numa alusão aos acontecimentos de Maio de 1810 que desencaderam a luta pela independência da Argentina do jugo espanhol, é significativa. Para o mesmo Alberto Palcos, Echeverría restabelece o pensamento de Maio de 1810, quando este começava a ser esquecido. A Asociación de Mayo recuperaria o princípio de uma "argentinidade", pouco mais de duas décadas após a independência.

Por esta interpretação, o caminho dos que lutaram contra o domínio da Coroa espanhola pondo fim à condição colonial, havia sido interrompido pela tirania de Juan Manuel de Rosas. A linearidade histórica e a filiação aos próceres da Nação eram requisitadas pelos integrantes da Asociación de Mayo. Assim como os combatentes de 1810 foram vencedores, a nova geração acreditava que obteria êxito. Mas as armas dos dois grupos marcavam uma diferença explícita entre eles: a geração de 1810, a mais gloriosa e valente, vencera pela espada; a nova geração, que expressaria a face adulta da pátria, lutaria com as armas da razão.

O grupo possuía um Codigo o Declaración de los Princípios que Constituyen la Creencia Social de la República Argentina, redigido em parte por Echeverría e publicado em sua primeira versão em 1839. Entre os princípios expostos neste Credo estava a defesa de uma revolução pacífica, que objetivava obter a adesão da juventude, do exército e dos grandes fazendeiros. A pretensão destes escritores de falar pelo país inteiro, como assinala Palcos, tornava-os semelhantes aos missionários do cristianismo primitivo ao propagar a fé. Agora a pretensão era difundir um projeto modernizador que poderia conciliar os grupos divididos na Argentina. Um aspecto a ser notado é o fato de intitularem-se como "socialistas". Porém, devemos compreender esta noção aproximando-a mais de uma sociabilidade do que daqueles sentidos que este termo adquiriu no próprio século XIX. Era 
ainda mais explícito, na questão nacional argentina, a libertação de uma "tutela intelectual" fruto de outros povos e tradições, valorizando-se, em contrapartida a própria realidade do país. ${ }^{9}$.

Os planos da Joven Argentina, fundamentados na defesa do progresso e da democracia, podem ser sintetizados nas famosas "Palavras Simbólicas".

1- Asociación. 2. Progreso. 3. Fraternidad. 4. Igualdad.

5. Libertad. 6. Dios, centro y periferia de nuestra creencia religiosa: el cristianismo su ley. 7. El honor y el sacrificio, móvil y norma de nuestra conducta social. 8. Adopción de todas las glorias legitimas, tanto individuales como colectivas de la revolución; menosprecio de toda reputación usurpada e ilegítima. 9. Continuación de las tradiciones progresivas de la Revolución de Mayo. 10. Independencia de las tradiciones retrógradas que nos subordinan al antiguo régimen. 11. Emancipación del espíritu americano. 12. Organización de la patria sobre la base democrática. 13. Confraternidad de princípios. 14. Fusión de todas las doctrinas progresivas em um centro unitario. 14. Abnegación de las simpatías que pueden ligarnos a las dos grandes facciones que se han disputado el poderío durante la revolución. ${ }^{10}$

Mesmo que as palavras não definam, ao sabor dos estudiosos do século XXI, um plano detalhado de ação, elas revelam algumas influências explícitas sobre o ideário dos jovens da "Geração de 37" e suas ambigüidades. Ao mesmo tempo em que se busca um caminho próprio por meio da "emancipação do espírito americano", da permanência dos princípios dos revolucionários de 1810 e da tentativa de uma unificação de antigos opositores, há a nítida influência dos acontecimentos ocorridos na Europa na década de 1830 como as Revoltas liberais.

Podemos identificar na lista de "Palavras Simbólicas" uma ordem universalista (que se pretende relacionada à tradição européia), uma americanista (ao falar de uma emancipação comum) e uma argentinista (tratando dos episódios como a Revolução de 1810 e as glórias desse passado local).

Estas questões, como observou Guillermo $\mathrm{Ara}^{11}$, são características da literatura argentina que se constituiu a partir de uma paulatina adaptação das idéias européias a um meio geográfico e étnico original bem diferenciado. Os temas locais surgem no repertório dos literatos da Geração de 37 como uma realidade a ser dissecada e, posteriormente, alterada. O desejo da ruptura com o passado e o legado hispânico é registrado como passos iniciais para a construção de um país novo. É esta a singularidade dos autores argentinos: a tradição fez com que se olhasse a paisagem interiorana, os pampas, como se fosse um espaço a ser ocupado. Esta área, também chamada de deserto, foi vista como uma dádiva para que os homens do século XIX pudessem construir o país moderno. O passado 
histórico, as populações nativas, o gaucho precisavam ser mudados para compor o ideal de uma nação que procurava sua identidade. $\mathrm{O}$ vazio permitia que se mirasse para a França como um exemplo civilizacional. Por mais que o discurso fosse o da construção de um caminho próprio, há a constatação, por parte desses autores, de que um caminho já fora trilhado com êxito por parte do Velho Continente que, evidentemente, excluía a Espanha.

Como observam os estudiosos sobre a literatura argentina do XIX, essa crítica ao universo bárbaro interiorano, em contraste com a "civilizada" Buenos Aires, esconde aspectos de admiração pela força com que os interioranos resistem a uma natureza imponente e humanizam um ambiente distante, "vazio" e hostil. O próprio Echeverría, que publicou o poema La Cautiva em 1837, introduz a questão de uma atmosfera especificamente argentina ao tratar de temas como os indígenas e os pampas, não como um feito heróico, mas como um problema que se apresenta para o projeto de construção nacional imaginado pelos liberais argentinos.

A tensão entre uma temática local (argentinista) e outra universal não deve ser vista como uma dicotomia insolúvel, pois dentro da concepção dos autores da Geração de 37, a Argentina tem uma especificidade, como qualquer outra região, e, ao mesmo tempo, integra uma tradição cosmopolita. Por outros caminhos e temas, retoma-se a discussão do início do século XVI sobre o pertencimento ou não do continente recém-descoberto ao "mundo" civilizado e, por extensão, qual o espaço de suas populações nativas dentro da civilização ${ }^{12}$. Com o surgimento dos Estados nacionais no início do século XIX, a indagação fundadora dos projetos nacionais era: a que tradição e em que processo histórico o país deveria se inserir?

\section{O conto El Matadero}

O conto El Matadero é extremamente provocante por trazer o tema do que era denominado 'barbárie', presente nos pampas, para a cidade de Buenos Aires. As críticas comuns ao interiorano são aplicadas também à população urbana partidária de Juan Manuel de Rosas. Nas ruas portenhas Echeverría mostra que a barbárie convive com a civilização: está incrustada nela e, portanto, suas fronteiras são tênues.

O argumento do conto é "narrar uma história", mas o narrador, sabidamente, não vai começar pela arca de Noé e pela genealogia dos ascendentes, como costumam fazer os antigos historiadores espanhóis da América. "Tenho muitas razões para não seguir este exemplo, mas me calo para não ser difuso... Os casos narrados aconteceram pelos anos de $183 \ldots$ Estávamos na quaresma, quando a Igreja proíbe que se coma carne"(...). "Como a Igreja tem, por delegação direta de Deus o império imaterial sobre as consciências e estômagos, que de forma alguma pertencem ao indivíduo, nada mais justo que se veja o mal”, escreve o autor. Houve um longo 
período de chuvas e os buenairenses, descritos de forma irônica como "tão fiéis ao princípio religioso", já não tinham as carnes, mesmo aquelas autorizadas para crianças e enfermos. O autor ironiza os próprios unitários como responsáveis pelas chuvas e pela crise de abastecimento ("Ai de vocês pecadores, ímpios unitários que não escutam com veneração à palavra dos eleitos do Senhor...”). Diante da escassez de carne, os partidários de Rosas ("o Restaurador") começavam a duvidar de sua capacidade de prover a nação com alimento tão necessário. $\mathrm{O}$ anúncio de que em um matadouro haveria o sacrifício de animais na proximidade do final da semana santa atraiu uma multidão que tomou as ruas da cidade. Ao perseguir uma rês que fugia, passou por cima de um "pobre inglês", mas a prioridade em agarrar o animal impediu que eles parassem a caçada para socorrer a vítima.

Echeverría faz um relato impressionante sobre o modo de matar os bois. O curral enlameado e as pessoas se digladiando até pelos miúdos dos animais provocam uma descrição "bárbara". No matadouro havia um juiz responsável pela organização e letreiros com os dizeres: "Viva o Restaurador e a heroína dona Encarnación Ezcurra, a mulher de Rosas!"; "Viva os federalistas"; "Morte aos selvagens unitários". A cena das 49 reses abertas sobre seu coro e o lamaçal do local do abate, após dias de chuva, se confundia com o sangue das artérias dos animais. A população, de "tez e raça distintas" se encontrava em torno do "carniceiro" com seu peito desnudo, rosto ensangüentado e acompanhado de muchachas negras... O carnicero jogava as partes e a população disputava o que era jogado.

O ponto máximo da história é quando a multidão encontra um jovem unitário, que fora reconhecido por não usar as insígnias ordenadas pelo "Restaurador". A multidão o persegue da mesma forma que havia feito com o touro do início do conto. A descrição de resistência, captura e morte, como ocorrida com o boi, é empregada na perseguição ao unitário. Os partidários de Rosas inquirem o jovem e, este, mesmo em desvantagem diante da multidão, demonstra a sua superioridade moral. Dirigindo-se corajosamente aos federalistas revela a feição animalesca do grupo: "A força é a violência bestial. Estas são as vossas armas, infames. O lobo, o tigre, a pantera também são fortes como vocês. Deveriam andar, como eles, de quatro patas". A turba ameaça desnudar, açoitar e violentar o jovem, que antes que isso se consumasse morreu de "nobre fúria". "O jovem estava fora de si de cólera. Todo seu corpo parecia estar em convulsão. Seu rosto pálido, sua voz trêmula mostravam o movimento convulsivo de seu coração." Por fim, "uma torrente de sangue brotou da boca e do nariz do jovem". A reação dos federalistas foi de espanto com o jovem unitário. Eles queriam apenas se divertir com o rapaz. Para o narrador, "os federalistas haviam dado fim a uma de suas inumeráveis proezas". No último parágrafo do conto as associações são ainda mais explícitas. 
Naquele tempo os carniceiros degoladores do matadouro eram os apóstolos que propagavam a vara e punhal a Federação rosista e não é difícil imaginar que federação sairia de suas cabeças e suas facas. Chamavam de selvagens unitários, conforme o jargão inventado pelo Restaurador, o patrono da confraria, a todos que não fossem um degolador carniceiro, nem selvagem, nem ladrão; a todo homem decente e de bom coração; a todo patriota ilustrado, amigo das Luzes e da liberdade; e, pelo sucesso obtido, pode-se ver às claras que o foco da Federação estava no matadouro. ${ }^{13}$

\section{A leitura política do conto e o "vazio cultural"}

O aspecto mais relevante em nossa análise sobre o conto El Matadero é a forma com que Rosas obtém o apoio da população de Buenos Aires. Como observa Nicolas Shumway, a opção de Echeverría não é apenas denunciar o caudilho que dominava a política argentina, mas a própria base de apoio popular ao seu governo. O país estava dividido entre unitários e federalistas que conviviam com os resquícios do período colonial recente e com a independência, que não havia adquirido o mesmo significado para toda a população. A idéia de nação e o papel exercido pela multidão, nas cidades e no interior, não eram os mesmos para os grupos políticos em disputa. ${ }^{14}$

As associações entre o matadouro e a Argentina de Rosas são explícitas e poderiam nos levar a um questionamento sobre quais as motivações para que Echeverría escrevesse um texto tão óbvio. Em primeiro lugar, não devemos nos esquecer que o conto teve publicação póstuma. Apenas 20 anos após a morte do autor, ocorrida em 1851 no exílio no Uruguai, é que o conto de 1838 foi recebido na Argentina. Quando publicado, quem estava na presidência da República era Domingo Faustino Sarmiento e a visão sobre o governo Rosas havia se transformado naquele país. A presença de um integrante da Geração de 37 na chefia do governo indicava um novo rumo político.

A necessidade de expressar a visão de Echeverría sobre a população portenha pode ser explicada por dois motivos: o primeiro, diz respeito à necessidade de se manter em alerta contra a "barbárie" que habita o espaço dos "civilizados"; o segundo, para glorificar o próprio grupo unitário que enfrentou os federalistas e a Mazorca, o aparato repressor de Rosas instituído em 1840 que perseguia os opositores. A geração de exilados que sobreviveu ${ }^{15}$, regressara ao país e poderia levar a cabo seu projeto, buscava legitimar-se na tarefa de preencher o vazio civilizacional que tanto os incomodava.

Havia uma memória sendo construída pelo grupo de literatos, que se outrora 
tinha um inimigo comum - o caudilho Rosas, agora enfrentava suas próprias divisões. Por este aspecto também podemos identificar a relevância do texto de Echeverría: a descrição do comportamento dos partidários de Rosas, que como vimos no conto disputavam os testículos e vísceras do touro e provocaram, de forma impiedosa, a morte do jovem unitário, mantinha acesa a imagem de um passado recente que precisava ser contraposto com a nova ordem política. Pretendia-se afirmar o acerto das ações políticas empreendidas dentro de uma esfera liberal, na qual os esclarecidos conduziam a Argentina ao seu "destino" de liderança e glória. O vazio, que sinalizamos na interpretação de El Matadero, está na leitura antipopular do que foi narrado. As multidões urbanas, tema recorrente e desafiador para o século XIX, adquirem outros significados na história Argentina. Pelas tintas da narrativa de Echeverría os grupos populares deveriam ser vistos com desconfiança. Esta visão é uma tônica freqüente naquele país. Não deixa de ser elucidativo que no território hispano-americano em que o discurso da civilização foi mais forte, o tema da população que constituía o novo Estado era apresentado como um desafio aos agentes da nova ordem política e cultural ${ }^{16}$.

A nação argentina não poderia surgir sem povo, mas ao mesmo tempo, quem era este povo? Necessitava-se da presença popular para fundamentar o poder inspirado na tradição liberal, na "defesa da democracia”, e no resgate que a Geração de 37 se propunha a fazer do "espírito de Maio de 1810". Mas, ao mesmo tempo, as lideranças políticas e intelectuais associavam a multidão urbana aos instintos animais, afirmando que "pensam mais com o estômago do que as consciências"17.

$\mathrm{O}$ vazio se apresentava para os literatos não como ausência, mas como algo a ser preenchido. $\mathrm{O}$ embate daquele grupo não era sobre um determinado excesso, pois isso equivaleria a defender o extermínio da população, mas a identificação do que precisava ser construído em meio a aqueles habitantes. Não é demasiado repetir que Echeverría expôs o que não havia sido dito: a barbárie é também urbana, e desta forma, o discurso civilizador, que adquire contornos mais explícitos em outros integrantes da Geração de 37, é o ponto que levará ao preenchimento desse vazio, instituindo normas e princípios que assegurassem a "modernização" e o "progresso" da Argentina. A consciência deste "vazio cultural", como caracteriza Gerald Martin, numa abordagem mais ampla sobre a América Latina, fez com que os intelectuais identificassem uma distância entre o universo vivido por eles e o sonhado com o legado francês.

Infelizmente, os intelectuais tenderam a agir como se cada uma das novas nações realmente estivesse tão vazia como parecia, um vazio cultural, uma folha de papel fantasmagoricamente em branco, legada, não pela Espanha ou Portugal, mas pelo Iluminismo francês, na qual eles poderiam escrever qualquer futuro que considerassem adequado. Os conquistadores 

século XIX

haviam sonhado com El Dorado; os intelectuais do XIX sonharam com utopias civilizatórias. Ficaram amargamente desapontados nessas primeiras décadas e em nenhum lugar mais que na Argentina, onde as expectativas eram as mais altas. $^{18}$

Echeverría, particularmente, expressava o incômodo de quem não conseguia se aproximar do que projetara.

\section{Fronteiras e hibridação}

A pergunta sobre o que a nação argentina deveria ser era uma preocupação dos escritores e políticos do século XIX. No debate entre a civilização e a barbárie é constituída uma fronteira que tem um grande alcance político e cultural. Os projetos em disputa (unitários e federalistas; civilizados e bárbaros) criavam o espaço de identificação, no qual manifestavam suas semelhanças e diferenças. Discutir a fronteira, principalmente para os escritores como Echeverría e Sarmiento, é uma forma de perguntar-se sobre até onde ela se estende e qual a sua legitimidade. As fronteiras que identificamos na literatura argentina do XIX nos permitem ler aquela nação. Da forma em que são enunciados, escritos, transcritos e inseridos em uma tradição, textos como El Matadero se consagram como monumentos em sua cultura.

No embate entre civilização e barbárie do século XIX, esta última tornouse um problema por ser o espaço não-ordenado pelo discurso do progresso. É o desafio da permanência de aspectos do passado colonial com os gauchos, indígenas e interioranos que não têm compromissos ou qualquer forma de crença absoluta no discurso urbano de tradição européia. O mundo cosmopolita, que Buenos Aires representaria, não era um valor a ser defendido. As descrições feitas por Echeverría no relato urbano El Matadero não abordam o exotismo (que para outras pessoas poderia ser lido como excessivo), mas introduz um tema de importância capital para se compreender o embate político da época: a temática do vazio civilizacional e da marginalidade. Ao descrever os comportamentos da multidão partidária de Rosas, o autor registra um mundo que está "à margem" do modelo que os intelectuais argentinos consideravam como o mais apropriado para a consolidação de seu país. A originalidade de Echeverría reside no ato de registrar a proximidade do conflito que ocorre no espaço urbano. A fronteira, para ele, não é geográfica, mas cultural e social. Ao definir as idéias e conceitos centrais (como vimos nas "Palavras Simbólicas") defendidos pelos integrantes da Asociación de Mayo, Echeverría define também o "outro campo" tornando explícita a tensão social existente na Argentina do século XIX. Mas esta tensão não é simplesmente a constatação de um confronto. 
Como escreveu Álvaro Fernandez Bravo, no discurso da constituição nacional a literatura é parte da definição das fronteiras, pois ela assume uma representação totalizadora que unifica e dilui toda aspereza em nome da nova unidade: a nação ${ }^{19}$. Para o literato do XIX, escrever é ocupar com discursos novos espaços simbólicos que irão superpondo junto à expansão das fronteiras e "preenchendo o vazio", por exemplo, refletido na idéia do progresso. As diferentes categorizações feitas dentro do perímetro da nação funcionam como oposições, mas também se articulam internamente. Ou seja, as fronteiras não são espaços exclusivos de confrontação, mas também de articulações. Deste modo podemos ver, ainda hoje, na Argentina e em toda a América Latina, a convivência entre pares aparentemente opostos: atraso e progresso; civilizado e bárbaro; unitário e federalista; peronista e anti-peronista.

A forma particular de convívio na Argentina e na América Latina não pode ser vista como excesso de uma sociedade que não realizou o seu papel diante dos discursos de fundação feitos desde as lutas pela independência. A história não é teleológica e as escolhas de cada povo e de cada sociedade foram feitas a partir das suas próprias circunstâncias. A dificuldade de análise desses processos históricos na América e o julgamento sobre suas nações a partir de critérios como os de progresso, de cidadania ou qualquer derivação deste discurso liberal europeu não pode se sobrepor à riqueza e peculiaridade dos processos históricos protagonizados por estes povos.

O discurso da fronteira, que produz determinados esquematismos e facilita a explicação na mesma proporção em que encobre as especificidades de cada processo, é desafiado pela crítica ao próprio re-conhecimento da condição de hispano-americano. Os diferentes papéis sociais que são desempenhados pelos povos da América se articulam em um jogo mais complexo do que a simples observação de dicotomias. O interior e a metrópole, os campos e as cidades, os "bárbaros" e "civilizados" partilham e confrontam códigos culturais de diferentes matizes. Mesmo assim, o modelo fixo da crença na civilização que era pretendida pelos literatos argentinos do século XIX, atualmente ainda tem um peso sobre os latino-americanos. Diante das evidências de um processo que não se realizou, tornam-se vítimas de uma representação decifrada como fracasso e impotência.

\section{Conclusão}

Na fundação da nação argentina, como vimos, a narrativa literária teve um papel fundamental. Por mais que os integrantes da Geração de 37 quisessem buscar algo próprio no esforço de inventar uma "particularização da nação", quando chegou a hora de dar sustentação a suas afirmações, pouco encontraram na Argentina que se conformasse aos planos anunciados por eles. Mesmo tendo criticado a Europa e os Estados Unidos pela tutela intelectual, essas regiões continuaram sendo um 

século XIX

farol para aqueles escritores. O americanismo que grassou em outras áreas das excolônias da Espanha, era visto como um obstáculo ao progresso. Por isso, podemos falar em um vazio ocorrido na ficção argentina do XIX: se propuseram o desafio de preencher um espaço, construir uma nação e dominar um extenso território. Esta estratégia discursiva, marcada por um traço da admiração pela Europa, estimulou a imigração e a destruição de comunidades pelo interior do país, para que a Argentina pudesse, enfim, realizar o seu "destino civilizacional".

Esta narrativa argentina pode ser considerada excessiva, pois a vontade de imitar a Europa e se distanciar de seu passado colonial foi gigantesca. Se houve excesso, é porque na recriação permitida pela imitação (mimesis), exagerou-se na idealização do que era a Europa. A constatação do vazio, que criou derivações como o discurso do isolamento e da solidão, era a mortalha que aprisionou aqueles escritores. Porém, da mesma maneira com que os discursos edificadores da nação, que povoam o imaginário argentino e latino-americano, o "vazio" se confronta com os processos europeus e norte-americanos. Ambos, o excesso e o vazio, continuam incomodando os habitantes desta região, pois projetam e sonham com uma América diferente daquela que é vivenciada cotidianamente com suas grandezas e mazelas.

Homens como Esteban Echeverría foram capazes de descrever a divisão e a convicção de seu tempo no discurso da civilização. Para derrotar a ditadura e a violência rosista criou-se um mundo estanque, supostamente sem comunicação. Quando há um lado tão certeiro e outro tão errado, devemos desconfiar dos discursos e pensar no que cada um deles projeta e o que cada um deles contém do outro. Vazio e excesso, por exemplo, se comunicam de acordo com as referências estabelecidos, da mesma forma que civilização e barbárie, justo e injusto, democracia e autoritarismo.

\section{BIBLIOGRAFIA}

ANNINO, A., GUERRA, F.-X. (orgs.) Inventando la nación. Iberoamérica, siglo XIX. México: FCE, 2003.

ARA, G. Introducción a la Literatura Argentina. Buenos Aires: Editorial Columba, 1966.

CORNEJO POLAR, A. O Condor Voa: Literatura e Cultura latino-americanas. Belo Horizonte: EdUFMG, 2000.

ECHEVERRIA, E. Obras completas. Buenos Aires: Ediciones Antonio Zamora, 1951.

ECHEVERRÍA, E. El Matadero IN: MENTON, S. El cuento hispanoamericano: antología crítico-histórica. México: FCE, 2003. 
FERNÁNDEZ BRAVO, Á. Literatura y frontera: procesos de territorialización em las culturas argentina y chilena del siglo XIX. Buenos Aires: Editorial Sudamericana/ Universidad de San Andrés, 1994.

GÁRATE, M.V. Civilização e barbárie n'Os Sertões: entre Domingo Faustino Sarmiento e Euclides da Cunha. Campinas, SP: Mercado das Letras/Fapesp, 2001.

LAERA, A. El tiempo vacio de la ficción. Buenos Aires: FCE, 2003.

MARTIN, G. A Literatura, a Música e a Arte na América Latina da Independência a 1870. IN: BETHELL, L. (org.). História da América Latina: da independência a 1870. v.3. São Paulo/Brasília: Edusp/Imprensa Oficial do Estado de São Paulo/ Fundação Alexandre de Gusmão, 2004

MARTÍNEZ, J. El cuento hispanoamericano del siglo XIX. IN: MADRIGAL, L. Í. (coord.) Historia de la Literatura Hispanoamericana del Neoclasicismo al Modernismo. (tomo II) Madrid: Ediciones Cátedra, 1993.

O’GORMAN, E. La invención de América. México: FCE, 1986

LARRAYA, A. P. Perduración romántica de las letras argentinas.México: UNAM, 1963.

PALCOS, A. Echeverría y la democracia argentina. Buenos Aires: Imprenta Lopez, 1941.

QUIJADA, M. ¿Qué nación? Denámicas y dicotomias de la nación en el imaginario hispano americano. IN: ANNINO, A., GUERRA, F.-X.. (orgs.) Inventando la nación. Iberoamérica, siglo XIX. México: FCE, 2003.

SARMIENTO, D. F. Facundo: civilização e barbárie. Petrópolis: Vozes, 1997 [1845].

. Argirópolis. Buenos Aires. Editorial Leviatan, 2005. [1850]

SHUMWAY, N. La Invención de la Argentina: historia de una idea. Buenos Aires: Emecé Editores, 2005

SVAMPA, M. El dilema argentino: civilización o barbárie: de Sarmiento al revisionismo peronista. Buenos Aires: Ediciones El Cielo por Asalto/Imago Mundi, 1994.

ZEA, L. (coord.). América Latina y sus ideas. México: Siglo XXI, 1986. 

século XIX

\section{NOTAS}

I Sobre esta questão ver a obra de SVAMPA, Maristella. El dilema argentino: civilización o barbarie. De Sarmiento al revisionismo peronista Buenos Aires: Ediciones El Cielo por Asalto/Imago Mundi, 1994. "La imagen 'Civilización y Barbarie' tuvo um primer empleo em Argentina al sintetizar el principio de legitimación política del liberalismo triunfante y uma estratégia de lucha para llegar ao poder. 'Civilización o Barbarie' fue desde el principio una imagem polisémica; su eficacia simbolica se hallaba relacionada con la capacidad de abarcar y enlazar distintas problemáticas y registros como como lenguages diferentes. Se insertó (...) em el dispositivo simbólico de la construcción liberal, dentro de un proyecto general de modernización. Dicha imagen expresaba cabalmente las dos dimensiones del proyecto civilizatorio: la exclusionista y la integradora." (p. 290)

2 Há um grande debate sobre o significado e o papel dos caudilhos na política hispano-americana. Um dos aspectos principais deste debate argumenta que estas lideranças, oriundas de setores tradicionais como o agrário e o militar, desempenharam papel crucial após as independências ao ocuparem o vácuo de poder deixado pela Coroa espanhola. Utilizando-se de mecanismos personalistas, como a troca de favores, os caudilhos exerciam uma liderança sobre seus domínios, recorrendo-se, inclusive, à adoção de violência e a vínculos paternalistas. Os caudilhos não tinham uma proposição política única. Na prática eles expressavam uma liderança baseada em seu prestígio pessoal, perseguiam os adversários e seus princípios políticos variavam conforme suas vontades.

3 A pesquisadora Miriam Gárate registra a associação entre os bárbaros e a ignorância feita por Sarmiento na epígrafe do seu "Facundo" e observada por outros literatos como Ricardo Piglia, já no século XX, quando afirma um caráter igualmente violento da associação feita pelos "civilizados" em relação aos nãoleitores: registra-se "o triunfo das idéias sobre a degola, dos poderes letrados sobre a força". (GÁRATE, M.V. Civilização e barbárie r'Os Sertões: entre Domingo Faustino Sarmiento e Euclides da Cunha. Campinas, SP: Mercado das Letras/Fapesp, 200 I. p. 32)

4 Cf. SVAMPA, Maristella. El dilema argentino: civilización o barbárie: de Sarmiento al revisionismo peronista. Buenos Aires: ediciones El Cielo por Asalto/Imago Mundi, 1994.

5 Um exercício comparativo entre a Argentina e o Peru, por exemplo, foi realizado pelo ensaísta Antonio Cornejo Polar no texto "Unidade, pluralidade, totalidade: o corpus da literatura latinoamericana" no qual ele aponta a presença de uma herança iluminista arraigada em alguns grupos literários hispano-americanos. Para o autor, devido à distância entre um discurso proferido por este grupo e a condição histórica para a sua realização é que se tem uma maior dramaticidade existente nas letras da Argentina, como em Facundo, se comparada à perpetuação de uma tradição barroca no Peru. No Peru, as contradições tenderiam a se dissolver na constituição de narrativas utópicas, ao passo, que na região do rio da Prata, estabeleciam-se os passos para a construção do projeto em disputa. Dentro dessa herança iluminista estaria o discurso, em diferentes regiões da América Latina, "feito por uma elite culta e destinado a cumprir tarefas civilizadoras junto a uma massa popular ingênua, enganada, inexperiente ou ignorante." IN: CORNEJO POLAR, Antonio. O Condor Voa: Literatura e Cultura latino-americanas. Belo Horizonte: Ed. UFMG, 2000. p. 37.

6 PALCOS, Alberto. Echeverría y la democracia argentina. Buenos Aires: Imprenta Lopez, 1941.

7 Segundo Nicolas Shumway ao mesmo tempo em que a Geração de 37, que contou com outros autores e tornou-se uma designação mais ampla do que o grupo originário que se reunião no Salão de Marcos Sastre, foi responsável por descrever os problemas do país daquela época, também criaram um gênero recorrente nas letras argentinas: a explicação do fracasso. Mesmo que a crença nas "idéias" e nas "palavras corretas", da qual partilhava o grupo, tenham sido insuficientes no embate político imediato, a presença da Geração de 37 no debate cultural argentino é extremamente forte. (Ver. SHUMWAY, Nicolas. "La Invención de la Argentina: historia de uma idea". Buenos Aires: Emecé Editores, 2005. p. $|3| ; \mid 45)$. O tema do fracasso, ou ainda de certa "inaptidão" da população em contraste com a visão 


\section{REVISTA ESBOÇOS N 20 - UFSC}

desse grupo de escritores é um dos aspectos que nos permite eleger o tema do "vazio" em Echeverría. A descrição parece ser continuamente a do que ainda falta para que se complete a "missão" argentina. Num outro texto de Domingo Faustino Sarmiento, Argirópolis ( 1850), fica explícita a idéia de que a Argentina tem o dever de conduzir a América hispânica.

8 Echeverría não é assertivo sobre o que ele compreende por socialismo. Mas entre suas influências estão as idéias de Saint-Simon, via interpretação fornecida por Pierre Leroux, um tipógrafo muito considerado à época. Mas mesmo esta aproximação com o "socialismo utópico" era rechaçada por Echeverría, pois considerava um absurdo aplicar um sistema pensado para as "nações mais avançadas da Europa" em "países submersos na barbárie". IN: Palcos, A. op. cit. p. 61.

9 Um ponto a ser observado é a crítica do escritor Paul Groussac, que afirmava que as idéias próprias de Echeverría para se pensar a Argentina, eram na verdade, plágios de Pierre Leroux e Giuseppe Mazzini. Mais do que as idéias de Pierre Leroux (1798-187|), reconhece-se a inspiração da Jovem Argentina no movimento liderado por Giuseppe Mazzini (I805-|872), a Jovem Itália. Este movimento republicano defendia a unificação italiana e se opunha à presença estrangeira naquele território.

10 Citado por MARTÍNEZ, Juana. El cuento hispanoamericano del siglo XIX. IN: MADRIGAL, Luís Ínigo (coord.) Historia de la Literatura Hispanoamericana del Neoclasicismo al Modernismo. Madrid: Ediciones Cátedra, 1993. (tomo II) p. 319.

I I ARA, Guillermo. Introducción a la Literatura Argentina. Buenos Aires: Editorial Columba, 1966.

12 Para esta discussão veja-se: O’GORMAN, E. La invención de América. México: FCE, 1986; ZEA, Leopoldo (coord.). América Latina y sus ideas. México: Siglo XXI, 1986.

13 Todos os trechos do conto, em tradução livre, foram extraídos de ECHEVERRÍA, Esteban. El Matadero IN: MENTON, Seymour. El cuento hispanoamericano: antología crítico-histórica. $7^{\mathrm{a}}$ ed. México: FCE, 2003. p. I3-32.

I 4 A historiadora Mónica Quijada propõe uma reflexão sobre o conceito de nação na argentina distinguindose três níveis conceituais: nação cívica, nação civilizada e nação homogênea. Por nação cívica, atrelada aos ideais dos primeiros anos após a independência, haveria uma justaposição de elementos heterogêneos que seriam orientados por um suposto "bem comum" que assumia a configuração das nacionalidades dos países nascentes, tornando-se "argentino", "uruguaio", "peruano", "chileno", "mexicano" etc. Por nação civilizada, décadas após a independência, surge o critério do "civilizado" em oposição ao "barbarismo nativo": as características da população nativa deveriam sucumbir ao que era mais apto para o "progresso", fazia-se uma "exclusão por fusão", que na Argentina, por exemplo, vinculou a "ação civilizadora" à "ação exterminadora" de indígenas na chamada "campanha do deserto". A nação homogênea, no final do século XIX e início do século XX, criticou os resultados das ações "civilizadoras" e distinguia os conceitos de Estado e de nação. Recuperava-se uma perspectiva de inclusão e do enriquecimento pelo fortalecimento de um "ideal coletivo intenso": as diferenças culturais, econômicas e políticas conviveriam com um imaginário simbólico comum. A nação homogênea, no entanto, não foi capaz de retirar das elites latino-americanas o ideal da "nação civilizada". QUIJADA, Mónica. ¿Qué nación? Denámicas y dicotomias de la nación en el imaginario hispano americano. IN: ANNINO, Antonio \& GUERRA, François-Xavier. (orgs.) Inventando la nación. Iberoamérica, siglo XIX. México: FCE, 2003. pp. 287-3I5.

$15 \bigcirc$ próprio Echeverría não fez parte deste grupo. Vítima de tuberculose, falecera um ano antes da queda de Rosas em seu exílio em Montevidéu.

16 Esta desconfiança dos liberais em relação à mobilização da multidão também pode ser vista na Europa, por exemplo, após a ação de grupos radicais durante as rebeliões de 1830 e I848, em Paris.

17 Durante o peronismo (1946-1955), uma trama parecida é usada por Jorge Luis Borges e Bioy Casares no conto "La Fiesta del Monstruo", objeto da análise de Paulo Renato da Silva em sua pesquisa de doutoramento na Unicamp.

I 8 MARTIN, Gerald. A Literatura, a Música e a Arte na América Latina da Independência a I870. IN: BETHELL, Leslie (org.). História da América Latina: da independência a 1870. v.3. São Paulo/Brasília: Edusp/Imprensa Oficial do Estado de São Paulo/Fundação Alexandre de Gusmão, 2004. p. 856.

19 FERNÁNDEZ BRAVO, Álvaro. Literatura y frontera: procesos de territorialización em las culturas argentina y chilena del siglo XIX. Editorial Sudamericana/ Universidad de San Andrés: Buenos Aires, 1994. p. 42. 